Check for updates

Cite this: RSC Adv., 2018, 8, 38614

\title{
Correlation between hydrogen yield and product distribution in algae conversion through an isopropanol/water system $\dagger$
}

\author{
Chunze Liu, Liping Kong, Anaerguli Wufuer, Yuanyuan Wang (D)* and Liyi Dai \\ This work reports a catalytic decomposition of algae to bio-oil over an isopropanol and water mixture \\ system. The $\mathrm{H}_{2}$ yield was adjusted by changing the ratio between isopropanol and water. In this system, \\ the introduction of formic acid was helpful to extend the yield range. Five noble metal supported \\ catalysts were applied and $\mathrm{Rh} / \mathrm{C}$ was proved to give the highest oil yield. A correlation was established \\ between hydrocarbon yield and $\mathrm{H}_{2}$ yield. It was useful in predicting product distribution and helping to \\ obtain desired products. EA, GC and GC-MS were applied in product analysis.
}

Received 24th August 2018

Accepted 26th October 2018

DOI: $10.1039 / c 8 r a 07090 c$

rsc.li/rsc-advances

In hydrogenation reaction, hydrothermal liquefaction (HTL)

\section{Introduction}

With the depletion of fossil fuels, renewable sources such as biomass have attracted research interest worldwide. As a third generation bioenergy, decomposing algae to fuels and chemicals has become a hotspot in recent years for its advantages such as higher photosynthesis efficiency, higher lipid content, higher growth rate and cultivation on saline-alkali land. ${ }^{1-3}$ Various conversion methods have been applied for the algae to bio-oil process including liquefaction, pyrolysis and hydrogenation. Among these, the liquefaction by sub- and supercritical fluid technologies has been widely applied in the algae conversion process to generate fuels and value-added chemicals. ${ }^{4-6}$ Gases and liquids are the most important products in algae bio-oil and always accompany and influence each other. In gas products, $\mathrm{H}_{2}$ often occupies a higher proportion and plays an important role in hydrogenation procedure, therefore could generate more alkanes in liquid oil and promote a high heating value (HHV) of the formed oil. Also, as a clean fuel source, $\mathrm{H}_{2}$ could be used directly. ${ }^{7}$

Early studies indicated that noble metal supported catalysts performed activities in the hydrogenation of algae products under high $\mathrm{H}_{2}$ pressure and temperatures. It is generally known that there are many heterogeneous atom compounds in algae cells and they can decrease oil quality dramatically. ${ }^{2}$ Catalytic hydrogenation combined with the existence of $\mathrm{H}_{2}$ could reduce heterogeneous atom content effectively. Common noble metals (Pd, Pt, Rh and $\mathrm{Ru})$ supported on active carbons were widely applied in algae hydrogenation reactions to form high yield high quality bio-oil. ${ }^{4}$

College of Chemistry and Molecular Engineering, East China Normal University, 500 Dongchuan Road, Shanghai 200241, China. E-mail: ecnu_yywang@163.com; Fax: +86 21-54340133; Tel: +86 21-54340133

† Electronic supplementary information (ESI) available. See DOI: $10.1039 / \mathrm{c} 8 \mathrm{ra07090c}$ was the most important technology for its advantages, such as avoiding large energy consumption process. However, it still remained some problems. As we all know, algae bio-oil was consisted by large amount of organic compounds, such as hydrocarbons, phenols, acids, esters, amides and other heterogeneous atoms compounds. Most of them couldn't dissolve in water, caused the reaction and separation problems. ${ }^{7}$

Alcohols as a series of protic solvents, can give more protons in hydrogenation reactions than water. As an organic solvent, it has better solubility for bio-oil than water. Also, it's cheap and can avoid dry process either. In previous research, methanol,, ethanol, ${ }^{9,10}$ propanol, ${ }^{11}$ isopropanol ${ }^{11}$ and ethylene glycol ${ }^{12}$ were investigated in algae conversion reaction and proved to having satisfied results. Especially, Duan and co-authors investigated them in thermal-chemical conversion of microalgae. ${ }^{11}$ In his work, five kinds of alcohols were applied and ethanol was proved to be the best. Nevertheless, isopropanol was noticed by our research group in recent years, for it could decompose to generate $\mathrm{H}_{2}$ and acetone., ${ }^{7,13}$ The $\mathrm{H}_{2}$ yield was much higher than methanol and ethanol for its unique structure. Also, it is cheap and can access easily. For its unique properties, it being thought to be a perfect $\mathrm{H}_{2}$ donator and solvent in algae decomposition process. In our previous work of lignin depolymerization, different ratios between isopropanol and water could cause different $\mathrm{H}_{2}$ selectively. Also, a correlation was established between liquid product distribution and $\mathrm{H}_{2}$ selectively. ${ }^{7}$ This result was helpful in predicting product distribution and the obtained desired product just through changing the ratio between isopropanol and water.

In this research, the influence on oil yield by different reaction conditions were investigated and then, different proportion of isopropanol and water were applied under catalytic liquefaction procedure. The composition and quality of formed biooil and $\mathrm{H}_{2}$ yield were detected. The connection between liquid 
Table 1 Characteristics of spirulina

\begin{tabular}{llllrl}
\hline Lipid (\%) & Protein (\%) & Carbohydrate $(\%)$ & C (\%) & H (\%) & N (\%) \\
\hline $7.60 \pm 1.20$ & $67.10 \pm 8.00$ & $15.30 \pm 2.00$ & $48.45 \pm 0.31$ & $7.13 \pm 0.19$
\end{tabular}

products distribution and $\mathrm{H}_{2}$ yield was given and formic acid was introduced to extend the variation range of $\mathrm{H}_{2}$ yield.

\section{Materials and methods}

\subsection{Materials}

Spirulina was purchased from Fuqing Xindaze Spirulina Co. The composition and results of the elemental analysis are listed in Table 1. Dichloromethane (DCM), formic acid $(\mathrm{HCOOH}$, 98\%), palladium nitrate $\left[\mathrm{Pd}\left(\mathrm{NO}_{3}\right)_{2}\right]$, and $\mathrm{Pd} / \mathrm{C}, \mathrm{Pt} / \mathrm{C}, \mathrm{Rh} / \mathrm{C}$ and $\mathrm{Ru} / \mathrm{C}$ (all element content of $5 \%$ ) were purchased from Sinopharm Chemical Reagent Co. Ltd. Absolute ethanol and anhydrous magnesium sulfate $\left(\mathrm{MgSO}_{4}\right)$ were purchased from Shanghai Chemical Reagent Co. Ltd. All the reagents were analytically pure (AR grade) and used directly without any purification. Characteristics of spirulina was shown in Table 1.

\section{Experimental procedure}

\subsection{Synthesis of Pd/HZSM-5}

HZSM-5 (Si/Al ratio of 80 ) was synthesized according to our previous work. ${ }^{13} \mathrm{Pd}\left(\mathrm{NO}_{3}\right)_{2}(0.6 \mathrm{~g})$ in a water solution $\left(15 \mathrm{mg} \mathrm{g}^{-1}\right)$ and $0.3 \mathrm{~g}$ of HZSM-5 was added to a beaker with $10 \mathrm{ml}$ of water. The mixture was stirred at room temperature for $24 \mathrm{~h}$. Then, the solution was placed in an oven at $120{ }^{\circ} \mathrm{C}$ for $10 \mathrm{~h}$. The dry powders were washed with water and filtered. After filtering, the catalyst was calcined in $\mathrm{H}_{2}$ at $400{ }^{\circ} \mathrm{C}$ for $4 \mathrm{~h}$.

\subsection{Catalytic conversion of algae}

A 304-stainless steel reactor with a volume of $30 \mathrm{ml}$ was purchased from the Yantai Muping Shuguang precision instrument factory. Algae ( $0.5 \mathrm{~g})$, solvent, and catalyst were added to the reactor. Then, the reactor was placed in a salt bath consisting of sodium nitrite, sodium nitrate, and potassium nitrate in the mass ratio $40: 7: 53 .^{14}$ Then, the reactor was heated to the specified temperature and kept for the desired residence time. After it was complete, the reactor was quenched by cool water for $40 \mathrm{~min}$ and then, gases were collected for the compositional analysis. $150 \mathrm{ml}$ DCM was used to wash the reactor so that all the products could be washed out. The mixture was filtered by a membrane with an aperture of $0.45 \mu \mathrm{m}$. After filtering, the solution was dried by $2 \mathrm{~g}$ of $\mathrm{MgSO}_{4}$. After another filtering by the membrane, the liquid was evaporated at $60{ }^{\circ} \mathrm{C}$ to remove the solvent, and the bio-oil product was obtained. Each experiment was repeated twice, and the average values of the oil yield are reported. The formulas for the oil and coke yields are given as

$$
X_{\text {Oil yield }}\left(\mathrm{wt}^{\mathrm{t}} \mathrm{s}\right)=\left(\frac{\text { weight of bio-oil }}{\text { weight of algae powder }}\right) \times 100
$$

\section{Characterization techniques}

\subsection{Elemental analysis}

The elemental compositions (C, H, and N) of the spirulina and bio-oil were determined using a Vario EL III instrument. For each experiment, the oil obtained from two experiments in parallel was mixed to obtain the results. The HHV was estimated using the Dulong formula: ${ }^{15}$

$$
\begin{gathered}
\mathrm{HHV}\left(\mathrm{MJ} \mathrm{kg}^{-1}\right)=0.338 \mathrm{C}+1.423 \mathrm{H}-0.154 \mathrm{O}-0.145 \mathrm{~N} \\
\mathrm{O}=100-\mathrm{C}-\mathrm{H}-\mathrm{N}
\end{gathered}
$$

where $\mathrm{C}, \mathrm{H}, \mathrm{N}$, and $\mathrm{O}$ are the weight percentages of each atom in the bio-oil.

\subsection{GC-MS analysis}

GC-MS analysis was performed using an Agilent Technologies 7890A-5975C instrument equipped with an auto-sampler and auto-injector. An Agilent HP-5MS column was used to separate the constituents. One microliter of a bio-oil solution with the DCM solvent was injected into the column. To protect the filament, a 3 min solvent delay was necessary. The column temperature was initially held at $40{ }^{\circ} \mathrm{C}$ for $3 \mathrm{~min}$; it was then ramped to $250{ }^{\circ} \mathrm{C}$ at $4{ }^{\circ} \mathrm{C} \mathrm{min}{ }^{-1}$ and held there for $10 \mathrm{~min}$, for a detection time of $65.5 \mathrm{~min}$. The analysis time was long enough to separate all the constituents. Helium served as the carrier gas. A Wiley mass spectral library was used to identify all the compounds. For each experiment, the oil obtained from two experiments in parallel was mixed to obtain the GC-MS results.

\subsection{GC analysis of product gases}

GC analysis of product gases was performed using an Tianmei GC 7890 with TCD detector. A Carboxen 1000 column was used to separate the constituents. For different product gases, different carrier gases were selected and the details were shown in Table 2. The gas sample was injected through six-way valve, split stream sampling was applied, split ratio was $3: 1$. The operation temperature of detector was $200{ }^{\circ} \mathrm{C}$ and the speed of carrier gas was $5 \mathrm{ml} \mathrm{min}{ }^{-1}$. The temperature of column was held at $70{ }^{\circ} \mathrm{C}$ and the totally analysis time was $60 \mathrm{~min}$.

Table 2 Parameters setting for GC

\begin{tabular}{lllc}
\hline Product gas & $\begin{array}{l}\text { Carrier } \\
\text { gas }\end{array}$ & $\begin{array}{l}\text { Background } \\
\text { gas }\end{array}$ & $\begin{array}{l}\text { Electric current } \\
\text { of TCD } / \mathrm{mA}\end{array}$ \\
\hline $\mathrm{H}_{2}$ & $\mathrm{Ar}$ & $\mathrm{N}_{2}$ & 70 \\
Carbon containing & $\mathrm{H}_{2}$ & $\mathrm{He}$ & 120 \\
gases & & &
\end{tabular}



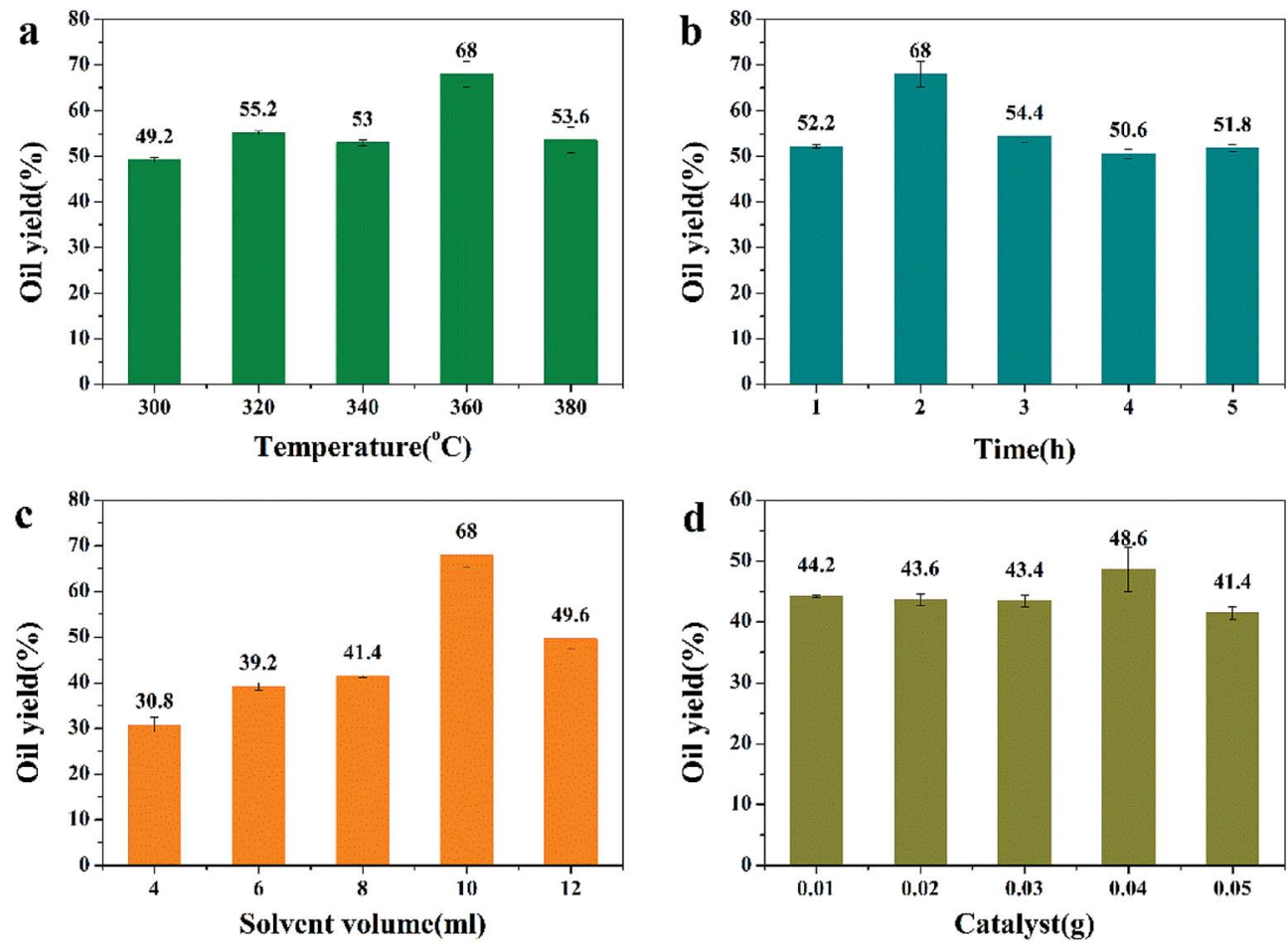

Fig. 1 Results of oil yield by different HTL reaction conditions. ((a) $0.5 \mathrm{~g}$ algae $+10 \mathrm{ml}$ isopropanol $+2 \mathrm{~h}$; (b) $0.5 \mathrm{~g}$ algae $+360^{\circ} \mathrm{C}+10 \mathrm{ml}$ isopropanol; (c) $0.5 \mathrm{~g}$ algae $+360^{\circ} \mathrm{C}+2 \mathrm{~h}$; (d) $\mathrm{Pd} / \mathrm{C}$ catalyst, $0.5 \mathrm{~g}$ algae $+360^{\circ} \mathrm{C}+10 \mathrm{ml}$ isopropanol $+2 \mathrm{~h}$.)

Table 3 Oil yield by different catalysts

\begin{tabular}{llllrl}
\hline Catalyst & $\mathrm{Pd} / \mathrm{HZSM}-5$ & $\mathrm{Pd} / \mathrm{C}$ & $\mathrm{Pt} / \mathrm{C}$ & $\mathrm{Rh} / \mathrm{C}$ & $\mathrm{Ru} / \mathrm{C}$ \\
\hline Oil yield/\% & $37.4 \pm 7.1 .2$ & $48.6 \pm 8.3 .6$ & $43.0 \pm 3.2 .2$ & $50.6 \pm 0.0 .4$
\end{tabular}

\section{Results and discussion}

\subsection{Results of reaction conditions optimization}

In our previous research work, isopropanol had not been applied in algae conversion reaction. Therefore, different reaction conditions were investigated first and the results were given in Fig. 1. In previous work, researchers found that temperature was the mainly influence fraction in bio-oil production, our former work also confirmed this. ${ }^{2}$ So, in Fig. 1a, $0.5 \mathrm{~g}$ algae and $10 \mathrm{ml}$ isopropanol was used in different temperatures. In Fig. 1a, when temperature increased from $300{ }^{\circ} \mathrm{C}$ to $360{ }^{\circ} \mathrm{C}$, oil yield increased from $49.2 \%$ to $68 \%$, revealed that high temperature was conducive to algae cell decomposition and isopropanol could receive higher oil yield

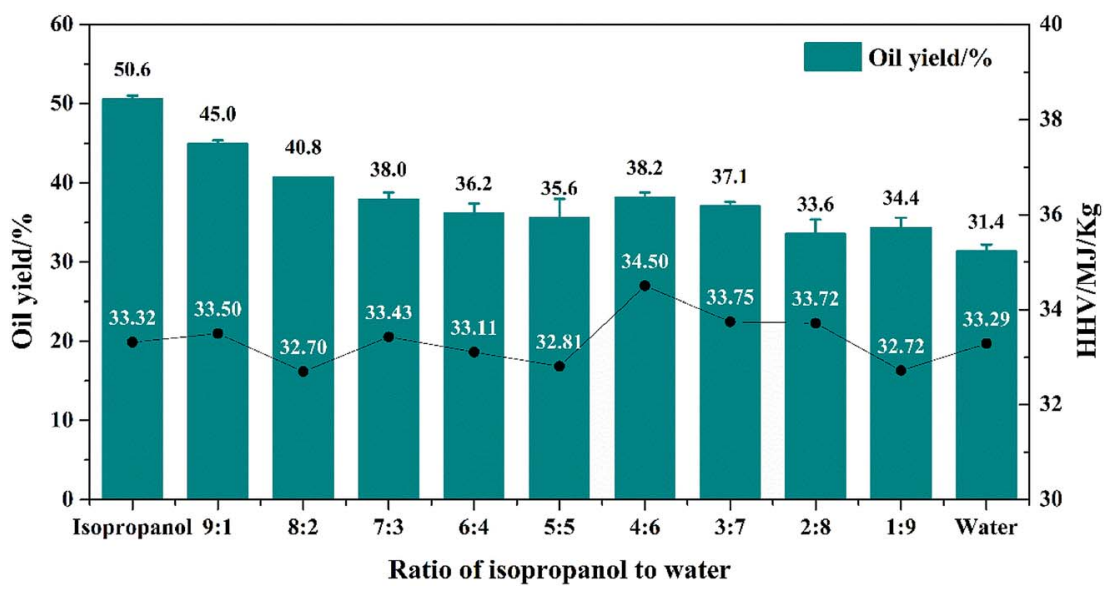

Fig. 2 Oil yield and HHV by different ratio of isopropanol to water. 


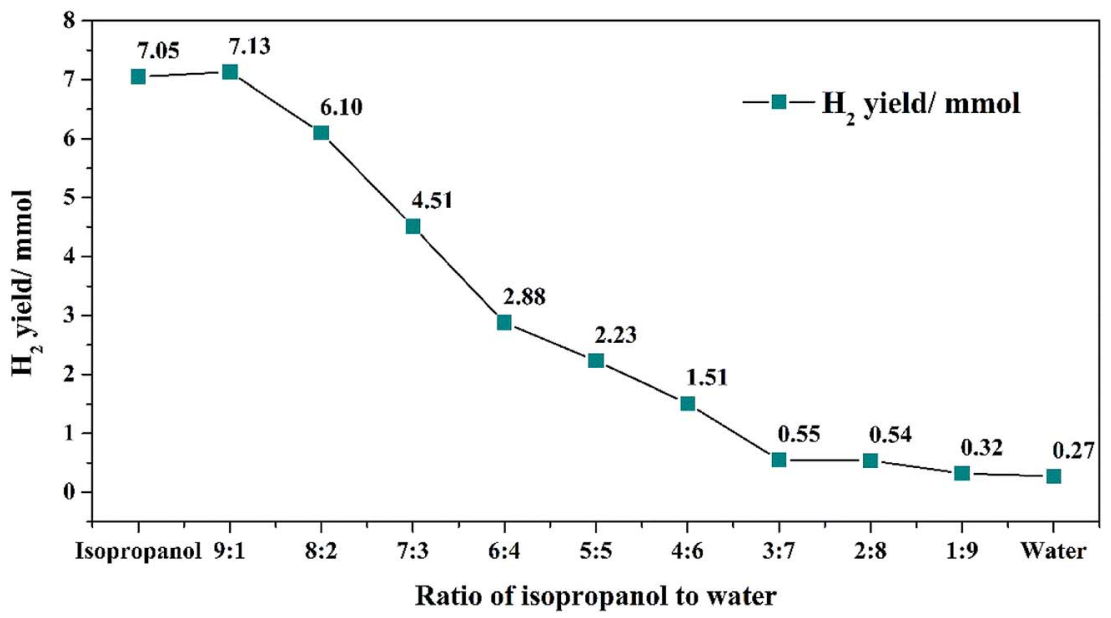

Fig. $3 \quad \mathrm{H}_{2}$ yield by different ratio of isopropanol to water.

than water, for it can polymerize to form larger molecules and stay in formed bio-oil. When temperature rise further to $380^{\circ} \mathrm{C}$, the oil yield decreased to $53.6 \%$, caused by re-polymerization of products. Therefore, $360{ }^{\circ} \mathrm{C}$ was selected to be the optimal. Then, the effect of reaction time was investigated and the results were shown in Fig. 1b. It was found that $2 \mathrm{~h}$ obtained the highest oil yield and prolonging reaction time caused oil yield decreased. The reason may be that the algae first decomposed to form bio-oil and then re-polymerized after $2 \mathrm{~h}$. Hence, in Fig. $1 \mathrm{c}, 2 \mathrm{~h}$ was chosen as the best and the effect of different isopropanol volume was given. When isopropanol volume increased from $4 \mathrm{ml}$ to $10 \mathrm{ml}$, the oil yield increased substantially from $30.8 \%$ to $68 \%$. But when $12 \mathrm{ml}$ isopropanol was hired in the reaction, the oil yield decreased to $49.6 \%$. It may be because that high isopropanol volume could cause high reaction pressure, this will accelerate the decomposition rate. In Fig. 1d, Pd/C was hired in catalytic decomposition reaction and the effect of catalyst dosage was given. In Fig. $1 \mathrm{~d}, 0.04 \mathrm{~g}$ catalyst obtained the highest oil yield of $48.6 \%$. On the basis of these results and for economic reasons, we chose a reaction temperature of $360^{\circ} \mathrm{C}$, a reaction time of $2 \mathrm{~h}$, an isopropanol volume of $10 \mathrm{ml}$ and a catalyst dosage of $0.04 \mathrm{~g}$ as the optimal reaction conditions.
In Fig. 1, it was found that the oil yield decreased when adding catalyst. It was considered to the decomposition effect of catalyst on isopropanol, that is to say, the existence of catalyst can promote the decomposition of isopropanol to generate $\mathrm{H}_{2}$ rather than itself polymerization. Based on these results, $\mathrm{Pt} / \mathrm{C}$, $\mathrm{Ru} / \mathrm{C}, \mathrm{Rh} / \mathrm{C}$ and $\mathrm{Pd} / \mathrm{HZSM}-5$ were applied in catalytic conversion of algae. The results were given in Table 3 and $\mathrm{Rh} / \mathrm{C}$ showed the best catalytic effect and obtained $50.6 \%$ bio-oil. In our previous research, Rh supported catalyst showed excellent effect in lignin depolymerization and deoxygenation..$^{15}$ Therefore, $\mathrm{Rh} / \mathrm{C}$ was hired in the next.

\subsection{Adjustability of the product distribution}

Based on the different $\mathrm{H}_{2}$-donating capabilities of isopropanol and water, different isopropanol/water ratios were used to adjust the proportion of $\mathrm{H}_{2}$ in the system. In the following experiments, $0.5 \mathrm{~g}$ algae, $360{ }^{\circ} \mathrm{C}$ reaction temperature, $0.04 \mathrm{~g}$ $\mathrm{Rh} / \mathrm{C}$ catalyst and $2 \mathrm{~h}$ reaction time and never changed. Also, the total volume of solvent was $10 \mathrm{ml}$. The oil yield and HHV were measured at nine isopropanol/water ratio. Also, system of pure water and pure isopropanol were conducted at blank experiments. These results were shown in Fig. 2. In Fig. 2, with the increasing of water volume, the oil yield decreased from $50.6 \%$

Table 4 Composition of bio-oil by different ratio of isopropanol to water

\begin{tabular}{|c|c|c|c|c|c|c|}
\hline $10: 0$ & 11.72 & 11.88 & 29.7 & 7.46 & 0.84 & 23.17 \\
\hline $9: 1$ & 9.42 & 11.7 & 32.72 & 4.39 & 0 & 25.04 \\
\hline $7: 3$ & 15.26 & 12.39 & 29.52 & 6.24 & 0 & 12.76 \\
\hline $6: 4$ & 18.08 & 14.98 & 17.23 & 2.71 & 1.61 & 31.79 \\
\hline $5: 5$ & 22.96 & 15.55 & 17.57 & 1.33 & 0 & 23.45 \\
\hline $2: 8$ & 18.29 & 4.2 & 46.79 & 2.77 & 0 & 11.74 \\
\hline $1: 9$ & 16.23 & 9.24 & 33.09 & 3.47 & 0 & 24.49 \\
\hline $0: 10$ & 15.88 & 9.35 & 28.44 & 4.75 & 0 & 21.54 \\
\hline
\end{tabular}

${ }^{a}$ Isopropanol. 


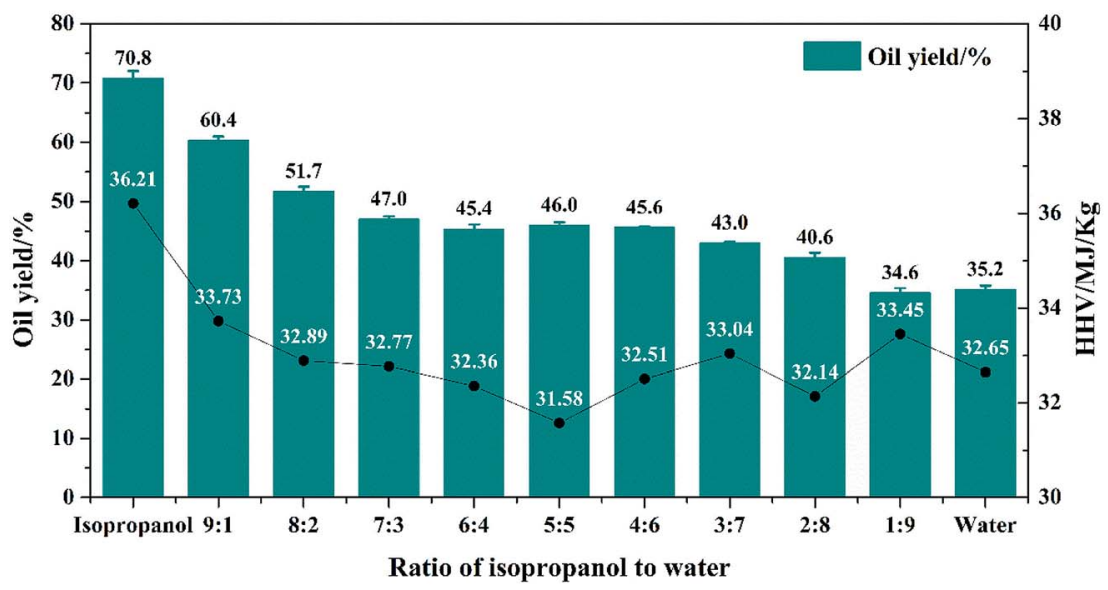

Fig. 4 Oil yield and HHV by different ratio of isopropanol to water with formic acid.

to $31.4 \%$. When the proportion of water increased to $40 \%$, the oil yield decreased obviously. This was attributed to the difference decomposition abilities between isopropanol and water. As the proportion of water further increased, the oil yield slowly decreased. It revealed that the depolymerization of isopropanol could increase oil yield and much more water had little effect on oil yield. At the same time, HHV of formed oil changed little with the changing of the isopropanol/water proportion, revealed that the effective of hydrogenation in this reaction system was limited, thus caused low oil yield and HHV.

$\mathrm{H}_{2}$ yield by different ratio of isopropanol to water were shown in Fig. 3. In Fig. 3, $\mathrm{H}_{2}$ yield decreased from 7.13 to $0.27 \mathrm{mmol}$ with the increasing of water volume. When water content reached to $50 \%$, the $\mathrm{H}_{2}$ yield decreased dramatically with the increasing of water content. When the water content increased after $70 \%$, the $\mathrm{H}_{2}$ yield was lower than $0.55 \mathrm{mmol}$, caused by the low $\mathrm{H}_{2}$-donating ability of the solvent. As we mentioned before, the $\mathrm{H}_{2}$-donating ability of the isopropanol and water were different, isopropanol was easily decomposed to form hydrogen. Therefore, when the ratio of isopropanol/water decreased, the $\mathrm{H}_{2}$-donating ability and the $\mathrm{H}_{2}$ yield of this system decreased.
The composition of formed bio-oil was determined by GC-MS and the results were shown in Table 4 . The content of formed biooil from Table 4 changed little with the changing of water volume. It may cause by the lack of $\mathrm{H}_{2}$-donating ability of the reaction system. Acids and amides occupied almost a half in biooil, indicated that the effect of hydrogenation was not satisfied. Also, the content of hydrocarbons and esters were low, it revealed that in catalytic liquefaction reaction, $\mathrm{H}_{2}$-donating ability of isopropanol was limited. As an in situ $\mathrm{H}_{2}$ donator, formic acid can decompose to generate $\mathrm{H}_{2}$ and it had been widely applied in hydrogenation reactions and received satisfied results. ${ }^{\mathbf{1 6 - 1 9}}$ Based on these, formic acid was introduced in the reaction system to improve $\mathrm{H}_{2}$-donating ability and received better results.

\subsection{Effect of formic acid on the adjustability of the product distribution}

When formic acid was introduced in the reaction, results of oil yield and HHV were shown in Fig. 4. Compared to Fig. 2, the introducing of formic acid can increase the oil yield and $\mathrm{HHV}$ obviously. Oil yield of isopropanol increased from $50.6 \%$ to $70.8 \%$ and also, oil yield decreased with the increasing of water volume. Besides, the oil yield had greater range of variation.

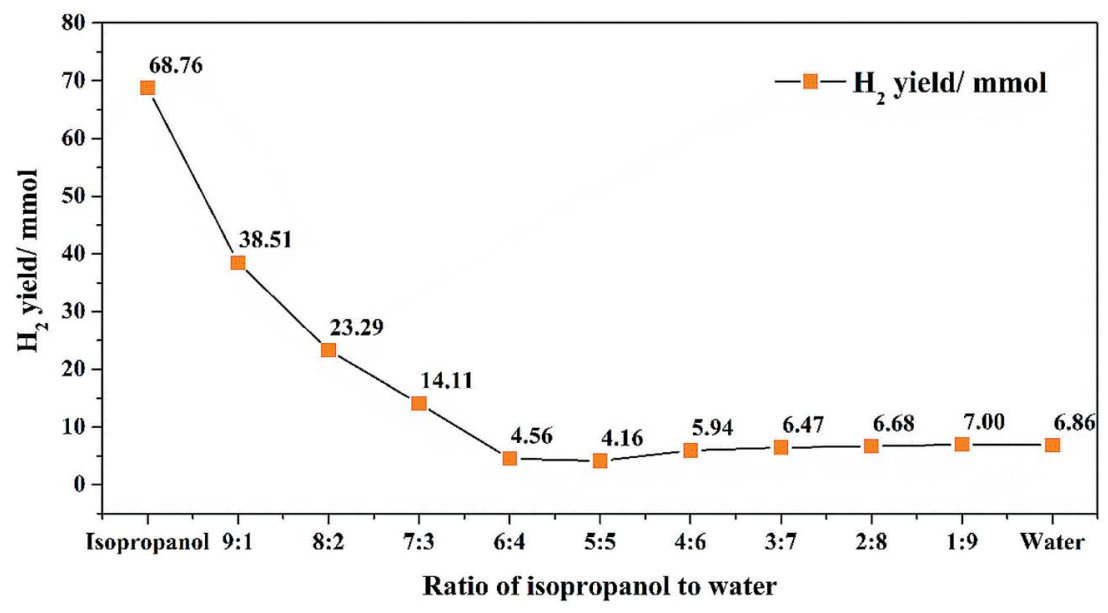

Fig. $5 \mathrm{H}_{2}$ yield by different ratio of isopropanol to water with formic acid. 
Table 5 Composition of bio-oil by different ratio of isopropanol to water with formic acid

\begin{tabular}{|c|c|c|c|c|c|c|}
\hline Ratio of i-PrOH ${ }^{a}$ to water & Hydrocarbons & Phenols & Acids & Esters & Nitriles & Amides \\
\hline $10: 0$ & 63.21 & 5.21 & 6.74 & 5.21 & 0.59 & 4.74 \\
\hline $9: 1$ & 52.07 & 7.07 & 10.78 & 6.03 & 0 & 7.24 \\
\hline $7: 3$ & 26.19 & 11.65 & 16.25 & 4.93 & 0 & 16.38 \\
\hline $6: 4$ & 19.25 & 11.92 & 18.06 & 5.04 & 0.62 & 18.26 \\
\hline $5: 5$ & 14.06 & 13.79 & 16.3 & 5.32 & 2.31 & 18.03 \\
\hline $2: 8$ & 11.73 & 16.13 & 22.62 & 2.49 & 0 & 24.49 \\
\hline $1: 9$ & 13.1 & 12.11 & 32.54 & 3.15 & 0 & 22.37 \\
\hline $0: 10$ & 13.98 & 12.44 & 28.14 & 2.65 & 0.99 & 18.75 \\
\hline
\end{tabular}

When the proportion of water increased to $30 \%$, the oil yield decreased from $70.8 \%$ rapidly to $47.0 \%$. As we mentioned before, adding water could decrease the $\mathrm{H}_{2}$-donation ability and the re-polymerization of isopropanol was limited, thus caused the decreasing of oil yield. When the proportion of water further increased to $80 \%$, oil yield changed little. Similar results were obtained in the oil yield without formic acid. When isopropanol was removed in the system, the oil yield decreased to $35.2 \%$ and it was $12.1 \%$ higher than that without formic acid. Nevertheless, the oil yield by isopropanol was $39.9 \%$ higher than that without formic acid, revealed that formic acid could have greater influence in the solvent which had better $\mathrm{H}_{2}$-donation ability. Also, in Fig. 4, with the introduction of water and removal of isopropanol, the HHV was decreased and isopropanol received the highest HHV of $36.21 \%$. But the HHV changed little when the proportion of water was greater than $20 \%$.

$\mathrm{H}_{2}$ yield with formic acid were shown in Fig. 5 and the composition of formed bio-oil was shown in Table 5. Compared to Fig. 3 , it can be observed that $\mathrm{H}_{2}$ yield $(68.76 \mathrm{mmol})$ increased dramatically. Also, with the increasing of water volume, $\mathrm{H}_{2}$ yield decreased quickly. The trend is the same as before. After the proportion of water higher than $40 \%$, the range of $\mathrm{H}_{2}$ yield changed little, may cause by the decreasing of solvent $\mathrm{H}_{2}$ donating ability. In this system, $\mathrm{H}_{2}$ yield could be controlled between 68.76 to $4.16 \mathrm{mmol}$, which was larger than that without formic acid.

In this system, adding formic acid could receive boarder range of $\mathrm{H}_{2}$ yield and this was similar with our former results. Therefore, GC-MS was applied in oil yield quality characteristics. The GC-MS results were shown in Table 5. In this Table, it was observed that in isopropanol oil, hydrocarbons yield was $63.21 \%$, it was much higher than that without formic acid. Also, the yields of phenols, acids, esters, nitriles and amides were both lower, indicated that this system had excellent

Table $6 \quad \mathrm{H}_{2}$ selectivity and yield by solvent

\begin{tabular}{lcc}
\hline & $\mathrm{H}_{2}$ selectivity $/ \%$ & $\mathrm{H}_{2}$ yield $/ \mathrm{mmol}$ \\
\hline Isopropanol & 7.52 & 0.80 \\
Isopropanol + HCOOH & 30.30 & 13.46 \\
Isopropanol + HCOOH + catalyst & 68.89 & 46.34
\end{tabular}

hydrogenation ability. Besides, with the proportion of water increasing, the yield of hydrocarbons decreased and the yield of acids and amides increased. At the same time, after the proportion of water higher than $40 \%$, the composition of formed oil changed little, this can match our previous conclusion. Based on these results, a correlation between $\mathrm{H}_{2}$ yield and the product distribution could be built. With the proportion of water decreasing, $\mathrm{H}_{2}$ yield from this reaction system increased and with the help of noble supported catalyst, hydrodenitrogenation and hydrodeoxygenation reactions were occurred to generate more hydrocarbons. Therefore, based on the ratio of isopropanol and water, we can give a prediction on product distribution and the relationship can help us to understand these complex reactions. This correlation between $\mathrm{H}_{2}$ yield and the product distribution furtherly emphasized the important of hydrogenation reaction in algae conversion process. Former, in the research of lignin decomposition by our research group, the correlation between $\mathrm{H}_{2}$ selectivity and the product distribution was given. ${ }^{7}$ But in algae decomposition process, the correlation between $\mathrm{H}_{2}$ yield (not selectivity) and the product distribution was established. It may be because that algae had more complex composition.

For comparison, blank experiments were carried out and the results were shown in Table 6. From this Table, it was observed that $\mathrm{H}_{2}$-donating ability of isopropanol was low and formic acid could decompose to generate more $\mathrm{H}_{2}$. Also, adding catalyst could promote the decomposition step of isopropanol and formic acid. Compared to Fig. 5, it revealed that algae could generate $\mathrm{H}_{2}$ in catalytic liquefaction, but limited. Therefore, in algae catalytic liquefaction reaction, isopropanol, formic acid and catalyst were both required.

\section{Conclusion}

Catalytic liquefaction of algae to bio-oil was investigated in isopropanol/water system at $360{ }^{\circ} \mathrm{C}$ for $2 \mathrm{~h}$. Different isopropanol/water ratio obtained different $\mathrm{H}_{2}$ yield and product distribution. The $\mathrm{H}_{2}$ yield was ranged from 7.05 to $0.27 \mathrm{mmol}$ by changing the isopropanol/water ratio. The introduction of formic acid was conducive to extend the $\mathrm{H}_{2}$ yield from 68.76 to $4.16 \mathrm{mmol}$. Also, oil yield and HHV by isopropanol was as high 
as $70.8 \%$ and $36.21 \mathrm{MJ} \mathrm{kg}^{-1}$, respectively. Besides, the relationship between $\mathrm{H}_{2}$ yield and product distribution was investigated and the correlation was proposed. It was helpful in predicting the composition of formed bio-oil.

\section{Conflicts of interest}

There are no conflicts to declare.

\section{Acknowledgements}

This work was financially supported by the National Science Foundation of Shanghai (No. 18ZR1411100).

\section{References}

1 Y. Chen, Y. L. Wu, D. R. Hua, C. Li, M. P. Harold, J. L. Wang and M. D. Yang, RSC Adv., 2015, 5, 18673.

2 C. Z. Liu, L. P. Kong, Y. Y. Wang and L. Y. Dai, Algal Res., 2018, 33, 156.

3 Y. Pierson, X. Chen, F. D. Bobbink, J. G. Zhang and N. Yan, ACS Sustainable Chem. Eng., 2014, 2, 2081.

4 Z. D. Huang, A. Wufuer, Y. Y. Wang and L. Y. Dai, Process Biochem., 2018, 69, 136.

5 M. Olkiewicz, M. P. Caporgno, J. Font, J. Legrand, O. Lepine, N. V. Plechkova, J. Pruvost, K. R. Seddon and C. Bengoa, Green Chem., 2015, 17, 2813.

6 P. G. Duan and P. E. Savage, Ind. Eng. Chem. Res., 2011, 50, 52.
7 J. Yang, S. T. Liu, C. Z. Liu, Y. Y. Wang and L. Y. Dai, Chem. Eng. Technol., 2018, 41, 867.

8 P. D. Patil, V. G. Gude, A. Mannarswamy, S. G. Deng, P. Cooke, S. Munson-McGee, I. Rhodes, P. Lammers and N. Nirmalakhandan, Bioresour. Technol., 2011, 102, 118.

9 X. Z. Yuan, J. Y. Wang, G. M. Zeng, H. J. Huang, X. K. Pei, H. Li, Z. F. Liu and M. H. Cong, Energy, 2011, 36, 6406.

10 H. J. Huang, X. Z. Yuan, G. M. Zeng, J. Y. Wang, H. Li, C. F. Zhou, X. K. Pei, Q. You and L. Chen, Fuel Process. Technol., 2011, 92, 147.

11 P. G. Duan, B. B. Jin, Y. P. Xu, Y. Yang, X. J. Bai, F. Wang, L. Zhang and J. Miao, Bioresour. Technol., 2013, 133, 197.

12 S. P. Zou, Y. L. Wu, M. D. Yang, C. Li and J. M. Tong, Energy Fuels, 2009, 23, 3753.

13 J. Yang, L. Zhao, C. Z. Liu, Y. Y. Wang and L. Y. Dai, Bioresour. Technol., 2016, 218, 926.

14 Z. Q. Hou, L. G. Luo, K. Liu, C. Z. Liu, Y. Y. Wang and L. Y. Dai, Chem. Eng. J., 2014, 236, 415.

15 J. Yang, L. Zhao, S. T. Liu, Y. Y. Wang and L. Y. Dai, Bioresour. Technol., 2016, 212, 302.

16 Q. Y. Bi, J. D. Lin, Y. M. Liu, H. Y. He, F. Q. Huang and Y. Cao, J. Power Sources, 2016, 328, 463.

17 X. Liu, L. He, Y. M. Liu and Y. Cao, Acc. Chem. Res., 2014, 47, 793.

18 Q. Y. Bi, J. D. Lin, Y. M. Liu, F. Q. Huang and Y. Cao, Int. J. Hydrogen Energy, 2016, 41, 21193.

19 J. G. Zhang and N. Yan, Green Chem., 2016, 18, 5050. 